\title{
Prevalence of Antimicrobial Resistance in Staphylococcus aureus Isolated from Ready to Eat Foods, Hand Swabs and Utensil Swabs of Street Vendors Selling Food on Wheels
}

\author{
Kuljinder Kaur* and R.S. Kahlon \\ ${ }^{1}$ Department of Microbiology, Mewar University, Rajasthan, India \\ *Corresponding author
}

\begin{tabular}{|c|c|}
\hline & A B S T R A C T \\
\hline Keywords & $\begin{array}{l}\text { The prevalence of antibiotic resistance of Staphylococcus aureus in } 50 \text { samples of } \\
\text { ready to eat food, hand swabs and utensil swabs of street vendors was studied. }\end{array}$ \\
\hline $\begin{array}{l}\text { Antimicrobial } \\
\text { Resistance, } \\
\text { Staphylococcus } \\
\text { aureus }\end{array}$ & $\begin{array}{l}58 \% \text { of samples were contaminated with } S . \text { aureus. The highest count } \\
\left(5.66 \times 10^{4} \mathrm{cfu} / 25 \mathrm{~cm}^{2}\right) \text { was found in hand swab samples. The antibiotic resistance of } \\
\text { the isolates was tested using } 12 \text { antibiotics. } 72.41 \% \text { isolates were resistant to } \\
\text { Erythromycin while } 31.03 \% \text { isolates were resistant to Ampicillin, Ofloxacin and }\end{array}$ \\
\hline Article Info & Sparfloxacin. Overall $62 \%$ of $S$. aureus isolates were multidrug resistant. The \\
\hline $\begin{array}{l}\text { Accepted: } \\
25 \text { April } 2017 \\
\text { Available Online: } \\
10 \text { May } 2017\end{array}$ & $\begin{array}{l}\text { and vendors serving hands are frequently contaminated with } S \text {. aureus and their } \\
\text { through food chain. This could be common route for spread of resistant } \\
\text { Staphylococcus food borne infections. }\end{array}$ \\
\hline
\end{tabular}

\section{Introduction}

Staphylococcal food-borne disease (SFD) is one of the most common food-borne diseases worldwide resulting from the contamination of food by preformed $S$. aureus enterotoxins. However, several studies have documented prevalence of $S$. aureus in many food products including raw retail meat indicating that consumers are at potential risk of $S$. aureus colonization and subsequent infection. S. aureus is a commensal and opportunistic pathogen that can cause wide spectrum of infections, from superficial skin infections to severe, and potentially fatal, invasive disease (Lowy, 1998). This ubiquitous bacterium is an important pathogen due to combination of "toxin-mediated virulence, invasiveness and antibiotic resistance." This organism has emerged as a major pathogen for both nosocomial and community-acquired infections. S. aureus can cause contamination of food products during food preparation and processing. S. aureus can grow in a wide range of temperatures $\left(7^{\circ}\right.$ to $48.5^{\circ} \mathrm{C}$; optimum 30 to $\left.37^{\circ} \mathrm{C}\right), \mathrm{pH}(4.2$ to 9.3 ; optimum 7 to 7.5 ), and sodium chloride concentration up to $15 \% \mathrm{NaCl}$. S. aureus is a desiccation tolerant organism with the ability to survive in potentially dry and stressful environments, such as the human nose and on skin and inanimate surfaces such as clothing and surfaces (Chaibenjawong and Foster, 2011). These characteristics favour growth of 
the organism in many food products (le Loir, Baron, 2003). S. aureus can remain viable on hands and environmental surfaces for extended durations after initial contact (Kusumaningrum et al., 1990).

The prevalence of antimicrobial resistance among food-borne pathogens has increased during recent decades. There is a growing tendency through the consumption of fast foods (hot or cold ready-to-eat foods), which increases the risk of food-borne diseases.

Improper food handling practices in the retail food industry are thought to contribute to a high number of FBD outbreaks (Lues, 2007). It was reported that the hands of food handlers were implicated in $42 \%$ of foodborne outbreaks that occurred between 1975 and 1998 in the United States (Ayçiçek et al., 2004.). In a recent study (Syne et al., 2013) investigated the microbiological contamination in ready-to-eat food products processed at a large processing plant in Trinidad, West Indies, S. aureus was the most common pathogen detected. The overall prevalence of $S$. aureus detected in air, food, and environmental samples was $27.1 \%$ (46/170). It was determined that the counts of $S$. aureus increased after heat treatment, and only post cooking environmental surfaces that came into contact with ready-to-eat foods that were contaminated with $S$. aureus during slicing and packaging harboured S. aureus. The hands of ready-to-eat food service employees have been shown to be vectors in the spread of food borne disease, mainly because of poor personal hygiene. Investigations of food borne illness outbreaks have shown that poor personal hygiene, primarily ineffective hand washing, is an important contributor to food borne illness, secondly to inadequate temperature controls of food (Scarborough, 2002). A number of data confirm that $S$. aureus cause many outbreaks of food poisoning resulting from hand contact (Bryant et al., 1988).
Antimicrobial resistance associated with food and water has been a global concern (Kumar et al.,). It is now widely accepted that there is an association between the use of antimicrobial agents and the occurrence of resistance. Antimicrobials exert a selective pressure on microorganisms that act as driving force in the development of antibiotic resistance. Moreover, there remains the possibility that resistance may be transmitted from antibiotic resistant bacteria to the susceptible ones (Kessie et al., 1998). Multidrug resistant bacteria in foods threaten the efficacy of human drugs if antimicrobial resistance genes become incorporated into bacterial population (Smith et al., 2002).

So the objective of this study was to investigate the prevalence of food-borne $S$. aureus in ready to eat food sold by street vendors, hand swabs and utensils swabs of food handlers and their susceptibility to commonly used antimicrobials. This will help to determine the potential hazards and public health implications that may be closely concerned with consumption of these foods prepared by street vendors.

\section{Materials and Methods}

\section{Sample description}

Ten samples of each ready to eat food (Vegetables burger, Vegetables momos, Noodles), hand swabs and utensil swabs of street vendors were taken. $100 \mathrm{gm}$ of each solid sample was taken with sterile forceps in sterile plastic zipper bag. Hand swab and utensil swab samples of food handlers were taken using sterile metal grid of $25 \mathrm{~cm}^{2}$ and sterile cotton swabs dipped in maximum recovery diluents. The swabs were then transferred to diluent tube. All the samples were transported to laboratory and analysed within 1 hour of collection or refrigerated at $4^{\circ} \mathrm{C}$ before being analysed. 


\section{Sample analysis}

$10 \mathrm{gm}$ of sample was taken in sterile stomacher bag containing $90 \mathrm{ml}$ of sterilized maximum recovery diluent (Hi-media).The sample was homogenised for 30 seconds using a stomacher to prepare uniform suspension. Serial dilutions of all samples were prepared in maximum recovery diluents (Hi-media). From each dilution tube, $0.1 \mathrm{ml}$ was spread on to each of the two agar plates (Blood agar and Baird Parker agar) in duplicate. The blood agar plates were incubated at $37^{\circ} \mathrm{C}$ overnight and Baird Parker agar plates at $37^{\circ} \mathrm{C}$ for $30 \mathrm{hrs}$. After incubation, typical colonies of $S$. aureus (Shiny black convex colonies with or without narrow grey white margins on Baird Parker agar and golden yellow coloured colonies on blood agar plates) were retained for further confirmation. Negative and positive control was also kept to compare the growth of colonies. The total number of viable colonies (cfu/gram) of sample was also determined (IS 5887-2).

\section{Characterization of isolates}

Isolates were confirmed as being $S$. aureus by the coagulase test (both slide and tube coagulase test). Further confirmation was done by catalase activity, growth in nutrient agar supplemented with $7.5 \%$ and $10 \%$ Nacl, nitrate reduction and Gram's staining.

\section{Antimicrobial susceptibility testing}

The susceptibility of Staph aureus isolates to antimicrobial agents was tested by disc diffusion method (Kirby- Bauer technique (Bauer et al., 1966) using Muller-Hinton agar and antibiotic discs (Hi-media) as per guidelines of the National Committee for Clinical Laboratory Standards (NCCLS, 2003. Performance standards for antimicrobial Disc Susceptibility tests, $8^{\text {th }}$ ed.
Approved standard M2-A8, NCCLS, Wayne, PA, USA.). Twelve antibiotics discs of Amikacin (AMK), Ampicillin (AMP), Amoxycillin (AMX), Azithromycin (AZ), Ciprofloxacin (CIP), Erythromycin (ERY), Clindamycin (CL), Tetracycline (TET), Gentamycin (GEN), Oxycillin (OXY), Ofloxacin (OFL) and Sparfloxacin (SPR) were used to test antibiotic sensitivity of Staphylococcus aureus isolates. The antibiotic discs were placed on the agar plates previously inoculated with $18 \mathrm{hrs}$ broth cultures of isolated test organisms. The plates were incubated at $37^{\circ} \mathrm{C}$ for $24 \mathrm{hrs}$. The size of the inhibition zones exhibited by test organisms against different antibiotics was measured. Results on the basis of zone diameter were recorded as sensitive, intermediate or resistant to a particular antibiotic with according to the NCCLS recommendations. Staphylococcus aureus MTCC 3160 was used as reference strain.

\section{MIC determination}

MIC determination was done as per guidelines of NCCLS, 2003(NCCLS, 2003. Methods for Dilution Antimicrobial Susceptibility tests for bacteria that grow aerobically, $6^{\text {th }}$ ed. Approved standard M7A6, NCCLS, Wayne, PA, USA.).

The cell suspensions were prepared using overnight growth of fresh culture of selected strains to give inoculum size according to 0.5 McFarland standards to determine MIC. The appropriate inoculum size used for standard MIC was $2 \times 10^{6} \mathrm{CFU} / \mathrm{ml}$. The working dilutions of antibiotics of different concentration used were prepared from stock solution. Using the multipipettor, $100 \mu 1$ of medium was dispensed into all wells of a microtitre plate. The plate and lid was labelled. $100 \mu \mathrm{l}$ of appropriate $2 \mathrm{x}$ antibiotic solutions was pipette into the wells in column 1 (far left of plate) of microtitre plate. Using 
the multipipettor set at $100 \mu \mathrm{l}$ mixed the antibiotics into the wells in column 1 by

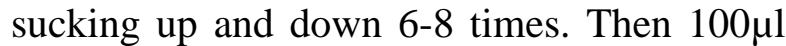
from column 1was withdrawn and added this to column 2. This made column 2 a twofold dilution of column 1 . It was mixed by sucking up and down 6-8 times. It was then transferred $100 \mu \mathrm{l}$ of column 2 to column 3 . The procedure was repeated down to column 10 only. $100 \mu \mathrm{l}$ from column 10 was discarded rather than putting it in column 11 . Thus column 11 was control without antibiotic. Inoculum with set inoculums size 2 $\mathrm{x} 10^{6} \mathrm{cfu} / \mathrm{ml}$ was poured into a sterile petri dish. With the smaller multipipettor set at 5 $\mu 1$, the wells of the microtitre plate were inoculated with $5 \mu \mathrm{l}$ of inoculum starting from columns 11 to 1 in that order. Inoculum was not added to column 12 (sterility control and blank for the plate scanner). Microtitre plates were incubated at $37^{\circ} \mathrm{C}$ for 24 hours. The purity of the bacterial culture was checked by streaking the bacterial cultures on Mueller-Hinton agar plates. When satisfactory growth in the form of turbidity was obtained after incubation of 18-36 hours, the microtitre plate was scanned for optical density (O.D) at $620 \mathrm{~nm}$ using an ELISA reader (TECAN).Using column 12 as the blank, MIC was taken as the lowest concentration of drug that reduces growth by more than $50 \%$ or $90 \%$ for $\mathrm{MIC}_{50}$ or $\mathrm{MIC}_{90}$ respectively.

\section{Results and Discussions}

Hands of ready-to-eat food serving vendors have been shown to involved in the spread of food borne pathogens mainly because of poor personal hygiene and which may account for approximately $97 \%$ of food borne illnesses in food service establishments and homes. Out of 50 samples taken for analysis, $58 \%$ of samples were contaminated with Staphylococcus aureus. In Table 1, the highest $S$. aureus count in the hand swab samples $\left(5.66 \times 10^{4} \mathrm{cfu} / 25 \mathrm{~cm}^{2}\right)$ and utensil swab sample $\left(2.628 \times 10^{3} \mathrm{cfu} / 25 \mathrm{~cm}^{2}\right)$ indicated that the food in question has been exposed to condition that might allow the spread of spread of pathogens. Food sample such as Vegetable Burger, Vegetable Momos and Noodles were also contaminated but highest count among food samples was in noodles $\left(3.5 \times 10^{2} \mathrm{cfu} / \mathrm{gm}\right)$. Although count from food samples taken was less than that of hand swab samples but it may increase with poor holding and handling of these ready to eat samples.

Staphylococcus aureus is an important food poisoning organism because of its cosmopolitan distribution in nature. Temperature of $30-37^{0} \mathrm{C}$ at which samples were collected favoured the growth of this organism. Outbreaks of Staphylococcus food poisoning have been reported to occur as the result of contamination of precooked food, often through unsanitary handling and holding food at temperature that allow the growth and toxin production (Newsome, 1988; Bergdoll, 1989; Syndor and Poland, 1991).

The microbial contamination of ready to eat foods could be closely related to preparing method and its handling. The sanitary condition of the environment under which these are being sold may also lead to their contamination. Highest count of staphylococcus in hand swab indicated that unwashed hands can transmit pathogens to food products during serving and dirty serving utensils may contribute to increase the count. Most of the food vendors lack proper education and adequate knowledge on how best food could be handled without contamination. Unsold product left are usually presented for sale the next day perhaps with gentle heat treatment could also be hazardous as some strains of Staphylococcus aureus have elevated thermal resistance, which cause inactivation by current culinary heating technique. 
Table.1 Average count of Staphylococcus aureus in ready to eat food and swab samples

\begin{tabular}{|l|c|c|c|}
\hline \multicolumn{1}{|c|}{ Sample } & $\begin{array}{c}\text { No of } \\
\text { samples } \\
\text { taken }\end{array}$ & $\begin{array}{c}\text { Percentage of samples } \\
\text { contaminated }\end{array}$ & $\begin{array}{c}\text { Average cfu/gm } \\
\text { or } \\
\text { cfu/ 25. } \mathbf{c m}^{\mathbf{2}}\end{array}$ \\
\hline Vegetable Burger & 10 & 50 & $2.2 \times 10^{2} \mathrm{cfu} / \mathrm{gm}$ \\
\hline Vegetable Momos & 10 & 30 & $1.3 \times 10^{2} \mathrm{cfu} / \mathrm{gm}$ \\
\hline Noodles & 10 & 10 & $3.5 \times 10^{2} \mathrm{cfu} / \mathrm{gm}$ \\
\hline Hand swab & 10 & 100 & $5.66 \times 10^{4} \mathrm{cfu} / 25 \mathrm{~cm}^{2}$ \\
\hline Utensil swab & 10 & 100 & $2.628 \times 10^{3} \mathrm{cfu} / 25 \mathrm{~cm}^{2}$ \\
\hline Total & $\mathbf{5 0}$ & $\mathbf{5 8}$ & \\
\hline
\end{tabular}

Table.2 Antibiotic Resistance in Staphylococcus aureus strains isolated from ready to eat food and swab samples

\begin{tabular}{|c|c|c|c|c|c|c|c|c|c|c|c|c|c|}
\hline \multirow{2}{*}{$\begin{array}{l}\text { Name of } \\
\text { the Sample }\end{array}$} & \multirow{2}{*}{$\begin{array}{l}\text { No. of } \\
\text { S.aureus } \\
\text { isolates } \\
\text { tested }\end{array}$} & \multicolumn{12}{|c|}{ Percentage Resistance to antibiotics } \\
\hline & & Amk & Amp & Amx & $\mathbf{A z}$ & Cipro & Ery & Cld & Tet & Gent & Oxy & Ofl & Spr \\
\hline $\begin{array}{l}\text { Vegetable } \\
\text { Burger }\end{array}$ & 5 & 60 & 20 & 60 & 60 & 60 & 100 & 60 & 40 & 60 & 60 & 40 & 40 \\
\hline $\begin{array}{l}\text { Vegetable } \\
\text { Momos }\end{array}$ & 3 & 67 & 67 & 67 & 67 & 67 & 67 & 67 & 67 & 67 & 67 & 67 & 67 \\
\hline Noodles & 1 & 0 & 0 & 100 & 0 & 100 & 100 & 0 & 100 & 100 & 0 & 0 & 100 \\
\hline Hand swab & 10 & 60 & 20 & 40 & 20 & 30 & 60 & 30 & 40 & 20 & 40 & 20 & 40 \\
\hline $\begin{array}{l}\text { Utensil } \\
\text { swab }\end{array}$ & 10 & 30 & 40 & 40 & 30 & 40 & 60 & 20 & 40 & 30 & 40 & 30 & 20 \\
\hline Total & 29 & 48.27 & 31.03 & 48.27 & 34.48 & 44.82 & 72.41 & 34.48 & 44.82 & $\mathbf{3 7 . 9 3}$ & 44.82 & 31.03 & 31.03 \\
\hline
\end{tabular}

Table.3 Multidrug resistance of Staphylococcus aureus isolates of different samples to selected antibiotics

\begin{tabular}{|l|c|c|c|}
\hline \multicolumn{1}{|c|}{ Sample } & $\begin{array}{c}\text { No of S.aureus } \\
\text { isolates tested }\end{array}$ & $\begin{array}{c}\text { Number resistant to 2 or } \\
\text { more antibiotics }\end{array}$ & Occurrence (\%) \\
\hline Vegetable Burger & 5 & 5 & 100 \\
\hline Vegetable Momos & 3 & 2 & 66 \\
\hline Noodles & 1 & 1 & 100 \\
\hline Hand swab & 10 & 5 & 50 \\
\hline Utensil swab & 10 & 5 & 50 \\
\hline Total & $\mathbf{2 9}$ & $\mathbf{1 8}$ & $\mathbf{6 2}$ \\
\hline
\end{tabular}


Table.4 MIC $(\mu \mathrm{g} / \mathrm{ml})$ determination of antibiotics in Staphylococcus aureus isolates of different samples

\begin{tabular}{|c|c|c|c|c|c|}
\hline \multirow{2}{*}{ Antibiotics } & \multicolumn{5}{|c|}{ Staphylococcus aureus isolates of different samples } \\
\cline { 2 - 6 } & SaVB & SaVM & SaN & SaHS & SaUS \\
\hline AMK & 32 & 64 & 32 & 32 & 32 \\
\hline AMP & 32 & 64 & 32 & 32 & 32 \\
\hline AMX & 32 & 16 & 16 & 16 & 32 \\
\hline AZ & 1 & 2 & 1 & 1 & 2 \\
\hline CIP & 8 & 8 & 16 & 4 & 8 \\
\hline ERY & $\mathbf{8}$ & 16 & 8 & 8 & 8 \\
\hline CL & $\mathbf{8}$ & 8 & 16 & 8 & 8 \\
\hline TET & 32 & 32 & 16 & 16 & 16 \\
\hline GEN & 32 & 16 & 16 & 16 & 16 \\
\hline OXY & 32 & 31 & 32 & 32 & 64 \\
\hline OFL & $\mathbf{8}$ & 16 & 16 & 8 & 8 \\
\hline SPR & 2 & 1 & 1 & 2 & 1 \\
\hline
\end{tabular}

*SaVB, SaVM, SaN, SaHS, SaUS (Staphylococcus aureus isolates of Vegetables Burger, Vegetables Momos, Noodles, Hand swab and Utensil swab)

The antibiotic sensitivity test with selected 12 antibiotics was conducted to detect the multidrug resistance among isolates of Staphylococcus aureus. Most of the isolated strains exhibited antibiotic resistance indicates that the ready to eat food products could also poses a public health risk to consumers.

Table-2 summarizes the resistance pattern of all the $S$. aureus strains to 12 antibiotics. The higher percentage $(72.41 \%)$ of the isolates was resistant to erythromycin while lower percentage $(31.03 \%)$ of isolates was resistant to Ampicillin, Ofloxacin and Sparfloxacin. Most of the strains resistant for Erythromycin were isolated from Vegetable Burger and Noodles samples. High resistance was also found $(48.27 \%)$ for Amikacin and Amoxicillin. Table-3 indicated that $62 \%$ of S. aureus strains were multidrug resistant (Resistance to two or more antibiotics). Although food and swab samples were obtained from street vendors at different locations and at different times, the isolates showed similar resistance pattern.
MIC of selected 12 antibiotics against only one isolate of Staphylococcus aureus of each category of sample was determined. Table 4 summarizes the MIC determination of selected antibiotics in Staphylococcus aureus isolates of different samples. The MIC $(\mu \mathrm{g} / \mathrm{ml})$ ranged between $1-64 \mu \mathrm{g} / \mathrm{ml}$. Highest MIC $64(\mu \mathrm{g} / \mathrm{ml})$ of Amikacin and Ampicillin was observed in Staphylococcus aureus isolates of Vegetables Momos and of Oxycillin in isolates of utensil swab. Lowest MIC $(1 \mu \mathrm{g} / \mathrm{ml})$ of Sparfloxacin was observed in Staphylococcus aureus isolates of Vegetable Momos, Noodles and utensil swab and MIC $(1 \mu \mathrm{g} / \mathrm{ml})$ of Azithromycin was observed in Staphylococcus aureus isolates of Vegetable Burger, Noodles and Hand swab samples.

The present study indicated that consumption of ready to eat foods contaminated with multidrug resistant strains of Staphylococcus aureus is fatal. This study also revealed that hand hygiene and utensil cleanliness was also unsatisfactory and may cause serious implications for public health due to 
contamination of food from food handlers' hands and their serving utensils. The food handlers need adequate training on both personal and environmental hygiene to prevent poor preparation, distribution and serving of food. There is great need to educate the street vendors especially in India selling ready to eat cheap foods on wheels about hazards of Staphylococcus aureus contamination. Control measures such as displaying foods in closed glass cabinets, washing hands at regular intervals, not serving food with bare hands and selling off all food items on the same day should be adopted to prevent food infections from occurring and developing in society. The antibiotic resistance pattern of isolates of Staphylococcus aureus in ready to eat food samples observed in this study suggest a greater risk in transfer of resistance to other bacteria because they can form commensal flora through food chain. The level of resistance to antimicrobial drug is a reflection of the indiscriminate misuse and abuse of antibiotics in the environment (Umoh et al., 1990; Chigbu and Ezeronye, 2003). A regular surveillance is required to detect the presence and detection of multidrug resistant contaminants in ready to eat food and their selling environment.

\section{References}

Ayçiçek H., Aydoğan, H.A., Küçükkaraaslan, M. Baysallar, and Başustaoğlu, A.C. 2004. "Assessment of the bacterial contamination on hands of hospital food handlers," Food Control., 15: 253-259.

Bryant, R.G., J. Jarvis and G. Gilbert. 1998. Selective enterotoxin production by a Staphylococcus aureus strain implicated in a food borne outbreak. J. Food Prot., 51: $130-131$.

Bergdoll, M.D. 1989. Staphylococcus aureus in food borne bacterial pathogens. Doyle M.P.(Ed). Marcel Dekker Inc,
New York, 463-524.

Baur, A.W., Kirby, W.M.M., Sherris, J.C., Truck, M., 1966. Antibiotic susceptibility testing by standardized single disc method. American. J. Clin. Pathol., 45: 493-496.

Chaibenjawong, P. and Foster, S.J. 2011. "Desiccation tolerance in Staphylococcus aureus," Arch. Microbiol., 193(2): 125-135.

Chigbu, C.O. and O.U. Ezeronye. 2003. Antibiotic resistant Staphylococcus aureus in Abia state Nigeria. Afr. J. Biotechnol., 2: 374-378.

Indian Standard 5887(II). 1976. Method for detection of bacteria responsible for food poisoning: Isolation, Identification and enumeration of Staphylococcus aureus and Faecal Streptococci.

Kessie, G., M. Ettayebi, A.M. Haddad, A.M. Shibi, F.J. Al Shammary. 1998. Plasmid profiles and antibiotic resistance in coagulase negative staphylococci isolated from polluted water. J. Applied. Microbial., 84: 417-422.

Kumar, H.S., A. Parvathi, I. Karunasagar. 2005. Prevalence and antibiotic resistance of Escherichia coli in tropical seafood. World J. Microbiol. Biotechnol., 21: 619-623.

Kusumaningrum, H.D., van Putten, MM. Rombouts, F.M. and Beumer, R.R., 2002. "Effects of antibacterial dishwashing liquid on foodborne pathogens and competitive microorganisms in kitchen sponges," $J$. Food Protection, 65(1): 61-65.

le Loir, Y., F. Baron, and M. Gautier. 2003. "Staphylococcus aureus and food poisoning,". Genetics and Mol. Res., 2(1): 63-76.

Lowy, F.D. 1998. "Medical progress: Staphylococcus aureus infections. The New England J. Med., 339(8): 520-532.

Lues, J.F.R. and van Tonder, I. 2007. "The occurrence of indicator bacteria on 
hands and aprons of food handlers in the delicatessen sections of a retail group," Food Control, 18(4): 326-332.

NCCLS. 2003. Performance standards for antimicrobial Disc Susceptibility tests, $8^{\text {th }}$ ed. Approved standard M2-A8, National Committee for Clinical Laboratory Standards, Wyane, PA, USA.

NCCLS. 2003. Methods for dilution Antimicrobial Susceptibility tests for bacteria that grow aerobically, $6^{\text {th }}$ ed. Approved Standard M7-A6, National Committee for Clinical Laboratory Standards, Wyane, PA, USA.

Newsome, R.I. 1988. Staphylococcus aureus Food Technol., 42: 194-198.

Scarborough, M.F. 2002. Hand Washing in Georgia's Public Schools - A Community Needs Assessment and Intervention Study, Master's thesis. Atlanta, United States: Emory University.

Scott, E and Bloomfield, S.F. 1990. "The survival and transfer of microbial contamination via cloths, hands and utensils," J. Appl. Bacteriol., 68(3): 271-278.

Smith, D.L., A.D. Harris, J.A. Johnsan, E.K. Sibergeld and J.G. Moris, Jr. 2002. Animal antibiotic use has an early but important impact on emergence of antibiotic resistance in human commensal bacteria. Proc. Natl. Acd. Sci. (USA), 99: 6434-6439.

Synder, O.P. and D.M. Poland. 1991. American's Safe Food part 2 Dairy, Food and Environ. Sanit, 11: 14-20.

Syne, S.M., Ramsubhag, A. and Adesiyun, A.A. 2013. "Microbiological hazard analysis of ready-to-eat meats processed at a food plant in Trinidad, West Indies," Infect. Ecol. Epidemiol., 3.

Umoh, V.I., A.A. Adesiyun and N.E. Gomwalk. 1990. Antibiogram of Staphylococcus aureus strains from milk and milk products. Zentrab. Vet. (B), 37: 701-706.

\section{How to cite this article:}

Kuljinder Kaur and Kahlon, R.S. 2017. Prevalence of Antimicrobial Resistance in Staphylococcus aureus Isolated from Ready to Eat Foods, Hand Swabs and Utensil Swabs of Street Vendors Selling Food on Wheels. Int.J.Curr.Microbiol.App.Sci. 6(5): 2424-2431. doi: https://doi.org/10.20546/ijcmas.2017.605.271 